\title{
CUSTOMARY RIGHT TO BEFITTING BURIAL: A JURISPRUDENTIAL APPRAISAL OF FOUR NIGERIAN CULTURES
}

\author{
Maurice Okechukwu Izunwa* \\ http://dx.doi.org/10.4314/og.v12i 1.6
}

\begin{abstract}
It is in the manifold customs of a people, precisely as the mirror of accepted usages, that their beliefs and worldview are screwed. Abstracted in symbols, a people's culture is preserved as long as it continues to be of value and thereafter for historical purposes. Notwithstanding that customs are largely unwritten; the norms they prescribe are codified, as it were, in symbols as statute books. These symbols reveal unique rights for the people's entitlement. Among the rights to which an African is entitled is the right to befitting burial/funerals. This right comes with it, certain duties and/or obligations. The aim of this paper is to deconstruct the elements of applicable burial customs with a view to demonstrating their afterlife implications as well as their social relevance. This is done through a phenomenologico-hermeneutical study of the symbols of burial rites in all four selected jurisdictions. It is the finding of this paper that this right of a befitting burial is next to the right to life in the hierarchy of customary rights and that it has a unique way of building the community in return. The mainstay of this work's recommendations is this that; to the extent this burial 'right' pass the tests for applicability of customs, as provided by the law, it should be promoted in every way and by every good means.
\end{abstract}

Key words: Customary Right, Cultures, Burial, Symbols, Man, Death, Afterlife

\section{Introduction}

Custom is a mirror of accepted usages (Oyewunmi v Ogunsesan, 1990). It relates to a rule which in a particular area has from long usage obtained the force of law (Evidence Act, 2011). Customary law on the other hand according to Okonkwo (1979) is 'a body of customs and traditions which regulate the various kinds of relationship between members of a community in their traditional 
setting (p.41). Hence Ehrlich cited in Iheme (1994) defines Nigerian customary law as "the organic or living law of indigenous people of Nigeria regulating their lives and transactions (p77). These organic laws give rise to various rights including the one under consideration.

In the words of Iheme (1995), a right is a legally guaranteed power to realize an interest. It is against some person or persons, to some act or omission of others and it is a right over or to something to which that act or omission relates (p.85). There are four elements in every legal right namely (a) the holder of the right (b) the act or forbearance to which the right relates (c) the object of the right and (d) the person bound by duty (Iheme, 1995). The customary right to befitting burial is an atypical right situate in an atypical customary jurisdiction. In its own way, it satisfies the conditions necessary for a legal right to inure, albeit contestable. For instance, the holder of the right is the deceased; the content of the right is joinder with the ancestors but before then, nobility of conduct in society; the object of the right is befitting burial/funeral rites and the person(s) bound by duty are family members or kinsmen.

The justification of this atypical right is the unique nature of an African community. An African community is populated not exclusively by its living members but also by the dead and yet unborn. It is a world not limited by its territorial boundaries but one which is continuous with the spiritual realms and consorting with both the animate, inanimate and spirited elements'. As it were, the African world permits a traffic of transactions to, fro and within the geo-spiritual 'ecology'. Hence in the proper African world, 'citizenship' is expansive and expanded to include the living and the dead even the unborn. In the same way, the concept of a person with right entitlements includes but is not limited to the living members of the community. The dead too, has rights one of which is the right to befitting burial.

Note also that; man stands alone in so many tangible ways that one can reasonably suggest that his stuff is quite beyond the animals. Cosgrove (1977), discerningly suggests that a glance at man's behaviour confirms that he is self conscious, has complex motivations and purpose (p.53). What is more, he transcends his present moment in time and is sufficiently possessed of expanded 
awareness. Precisely as having purpose, in being self conscious and sharing some expanded awareness, man is capable of using signs and symbols to express his ideas, beliefs, visions and expectations. In these very symbols, his world views are preserved and transmitted from generation to generation. No doubt, man's encounter with world realities happens in groups and communities, forming discernible cultural patterns. Hence, among men, there are common historical, religious, social, cosmological and linguistic experiences of the world leading to the emergence of particular cultures.

As a matter of fact, so many as there are groups of people in Nigeria sharing common visions and orientations, even so, are there many types and forms of symbolic identities and expressions, hence cultures. Therefore, attitudes and responses to events are all functions of man's perception of his world. World views shape actions and reaction to life events especially at the ritual realms. They determine even the stuff and texture of ceremonies at the deeper levels of meaning. This is all the more true in respect of those events associated with the origin and end of man, of those that translate him to high or different levels of awareness. The questions of both life and death are indeed at the centre of such events. Man's anxiety to demonstrate meaning is sharper upon such rites de passage precisely because at those points, of conscious and/or unconscious experiences, the synthetic- expressive capacity of man is brought to full concentration. As it is, on such events as burial ceremonies, man as the user of symbols, tries to show-case his idea of himself, also that of death and its causes, and more especially the idea of hereafter.

\section{The Idea of Culture and Nigerian Cultures}

Culture is sociologically used to denote that body of historically developed, shared, learned behaviour of the members of the society. As a concept, it encapsulates such common group behaviours as dressing, eating, dancing and as in context, burial forms and types. According to Mooney, Knox and Schacht (1997) cultures refer to the meaning and ways of life that characterize a society. Simply put, culture is about the way of life of a people.

The elements of culture are varied, but principally they include beliefs, values, sanctions and symbols. For Mithnow (1987), 
these elements are what together comprise the symbolic and expressive aspects of a society. Beliefs are a people's definitions and explanations of what they assume to be true. These beliefs not only influence how a social condition is interpreted, they also influence the existence of the condition itself. Values on their own right are social arrangements about what is considered good and bad, right and wrong, desirable and undesirable. Values play an important role not only in the interpretation of a condition as a social problem, but also in the development of the social condition itself. When people cherish some set of values and do not feel any threat to them, they experience well-being. The third element of culture relates to Norms; they are socially defined rules of behaviour. As Homans (1974) puts it, a norm is like "an idea in the mind of the members of a group, an idea that can be put in the form of a statement specifying what the members or other (people) should do, ought to do, are expected to do, under a given circumstance" (p.2). Whenever norms are violated, sanctions follow as consequences. Sociologists identify three types of norms: folkways, laws and mores. While folkways refer to the customs and manners of society which are not required by strict laws, laws are norms that are formalized and backed by the political authority of a given society. However, those norms that appear to have moral basis are called Mores. Violation of mores may produce shock, horror and moral indignation.

A symbol is something representing something else. The social nature of human interaction depends on the unique ability of humans to use symbols. Mooney, Knox and Schacht (1997) insist that without symbols, we cannot communicate with each other or live as social beings (p.8). The symbols of a culture include language, gesture, and objects whose meanings are commonly understood by the members of a society.

From the foregoing, it is easy to locate Burial Ceremonies within the domain of customs, in this case, a group's response to their experience, nay, beliefs about Death. This typical folkway of passage, being cast in symbolism, is thus sustained through traditions and praxis in diverse cultures. Social groups are differentiated from each other by their different attitudes, beliefs, language, dress, manners, tastes in food, music and a host of other features which comprise a way of life. Dewey (1929) strengthened 
this position by arguing that the distinctions between one social group and another compose of an organic intellectual and moral quality in the form of emotions, thoughts and practices (p.122). It becomes clear to any inquiring mind that whole societies have different cultures or way of life. The modern societies particularly are becoming increasingly culturally fragmented such that it is now difficult to have a monolithic culture in any one social group, hence, the propriety of the usage, 'In Nigerian Cultures'.

Nigeria is a multi-ethnic nation. Indeed it is not quite settled how many ethnic groups that constitute the entity Nigeria. According to Falola (2001) Nigeria derives from over 250 ethnic groups and languages (p. 4), some other scholars like Azikiwe (1994) provide for well over four hundred of such ethnic groups in Nigeria (p. 13). It is therefore expected that a multiple of cultural groups are identifiable within the country. Even within particular ethnic groups, several subcultures emerge to distinguish yet a class within the groups. For this, the concept of Nigerian cultures does not merely mean the ensemble of the cultural heritage of the various ethnic groups or tribes but goes beyond that to delineate variety of patterns of life attitudes that characterize groups and peoples. Yet, it trite that within any particular ethnic group there are peculiar patterns of cultural element that could be said to define and integrate them. And so, in having to write on Nigerian cultures, this work picked on such large groups as Igbo culture, Yoruba, Esan, and Tiv cultures, so far as space allows; the list is to wit difficult to exhaust. It is in this connection that Alaezi (1990) understood Nigerian cultures when he wrote that "there are well over 450 different languages and perhaps the same number of cultures in Nigeria."

\section{Death, a Prerogative of Man}

Bronowski (1973) in his 'The Ascent of Man', describes man as being quite unique among all other animals. Being greatly prepared with reason, memory, imagination and spirituality, he is not just a figure in the landscape- he is a shaper of the landscape. Precisely, in being capable of self-transcendence, he is not merely a citizen of this earth but extends beyond the frontiers of materiality to the vision and experiences of death and after life. According to Mondin (1985), man, by a characteristic intuition, continually surpasses himself, all 
that he is, and all that he wishes even all that he has (p.199). And so, with this, his capacity to transcend himself and without having experimented with death, man reaches out beyond the graves to shape his next life. This is essentially what he anticipates in the structures of the burial ceremonies as variously found in all cultures.

Far from the merely clinical and biological concepts of death which have meaning only for technical parametrics, a people's understanding of death is culturally determined. This understanding, in turn, remotely fashions the contents and forms of the burial ceremonies across cultures. Yet, as Ukagba (2007) puts it, in all cultures, there is this common perception that death is a process whereby the physical life of a human being ceases, changes and continues in a spiritual form in another world. Therefore despite all manners of cultural specifics in burials, motifs of cessation, change and continuity frequently rear up. Also, as Mondin (1985) recognizes, there appears to be not one cultural group that does not cognize death as a universal experience, inescapable, imminent, inexorable and fearful (p. 265). All these shared understanding obviously have some place in one way or another, in the burial rituals.

\section{Burial Motifs in Cultural Differentials}

It is not easy to isolate burial ceremony per se from funeral ceremony. Yet while the funeral ceremony appears to cover the entire vistas of the various rites, rituals and observances, whether socio-religious or psychological which functions to accompany the deceased to the world beyond, the burial ceremonies appear specified and limited to the actual symbolic observances that are immediately connected with interment, that is, of the ritual acts linked with committing the dead to the mother earth. Funeral ceremonies extend to include the merely socio-psychological dimensions, of the mourning entailments. Whichever way it goes, one technically observes a thin divide between the two. Hence in discussing the burial ceremonies, what may ordinarily appear to belong to the properly funeral, could be highlighted and involved so far as it assists in the sociological description of the burial practices.

Generally, a people's eschatological vision, that is, their view about the after-life goes a long way to fashion how they bury 
their deceased members. For instance, as Ebeh (2007) puts it, Africans are particularly known to think of the next world when they interred their deceased members in the graves with those house hold utensils that he or she uses in this present world. Interestingly, this very burial attitude is not exclusive to though predominant of Africans, but so much to be found among all peoples who share similar visions of the next life. Hence, according to Hinnells, among Egyptians:

...at all levels of society the dead were supplied with funerary goods for the afterlife. For the wealthy, these included anthropoid and rectangular coffins, face-masks, canopic jars (containing viscera), funerary jewellery, amulets, butchers and bakers to prepare a continuing source or victuals. Hundred of ushabits (mummiform figurines representing agricultural labourers) provided the deceased with a MAGIC work-force (p.180).

In Nigeria, where there is a conglomerate of diverse cultural patterns which share some similarities, patterns of burials meet and cross paths, nay, with heavy peculiarities. This work principally examined the Igbo cultural area, and proceeds randomly to tinker with a few others namely: Yoruba, Tiv and Esan.

\section{In the Igbo Culture}

Nwala (1985) observes that among the Igbo, death implies merely dissolution of the flesh and not the end of life. Therefore, the grief at the death of a man is usually because of the sense of loss of his physical presence. As a matter of fact, "the institution of mortuary (burial) among the Igbo is very elaborate and it illustrates much that is found in Igbo philosophy of life (p. 41). For instance, their belief in an unending existence in the next life leads to elaborate burial rites to ensure an honourable place for the dead in the spirit world. A typical burial ceremony in Igbo culture embraces a variety of functions and rituals to be mediated by the sons, kinsmen (umunna), age grades and secret societies, to mention a few.

Where burials are well done among the Igbo, they compose of a whole lot of symbolic rituals comprising acts meant to first 
effect a ritual separation from the living members of the human society while establishing in the beyond a company with the ancestors. From there, a new kind of relationship or some form of spiritual communion with the living can be re-arranged. The workability of this circularity depends, according to Metuh (1987), on the functionality of the burial ritual (p. 252). It is widely believed by the Igbo that where a burial ceremony is unbefittingly organized, the spirit of the dead person precisely as being unsettled and furiously wandering would continue to hunt the living. Kalu (1979) clearly explained this to the effect that once improperly buried, the spirit of the dead "would be unhappy and would probably return as evil spirits for vengeance" (p.15). Most often, the organization of yet another burial is always the remedy to such infernal onslaught. The Igbo view death as a movement from "here" another similar in character, with the possibility of a return to "here". Sequel to this belief, they accompany the dead with some or all of the implements or symbols or property with which he had lived, all with the belief that beyond the scene, same life continues in identical conditions. Kings (ndieze) are for instance buried with slaves and the insignia of their office like the staff (in the olden days).

Next, the type and quality of burial which is accorded a person depends on the life such a person led and the type of death that followed. Metuh (1987) points out that within the Igbo community, a person dies naturally at ripe old age - Onwuchi (p.133), or is otherwise said to die a bad death. For Onwuchi to crystallize, Agbasiere (2000) highlights that the victim also needed to have lived a good life (p.144), married with children and have not died within a solemn festivity. Anybody that dies outside these set criteria for good death, is said to have met a bad death- ajo-onwu. Included in the class of bad death are those who die as repeaters (Ogbanje) or in abject poverty and unprovided for. For Onah and Leman (2007), all manners of sudden deaths (by fire, water, automobile accident and death by suicide) are ajo-onwu (p. 60). Concerning a person who dies a natural death, the burial rites are richly and satisfactorily carried out with a mixed feeling of sadness for having to miss his or her companionship and joy in celebration of a fulfilled life. Such burials are usually with a lot of eating, drinking, 
dancing and cultural displays. These help to appease the spirit of the dead and clear the spiritual traffic as the dead undergoes transition.

With regard to those who have suffered unnatural death (ajo-onwu), the burial atmosphere is usually sad; depending on the degree or type or circumstances of such death, there could be a low key burial or none at all. In some disturbing cases of bad death like Ogbanje, the victims are mutilated before relatives in other to prevent such persons from re-incarnating. The burials of such, where they are observed at all, are done with ignominy. Some of them are cast into the evil forest (ajoofia), and their memories allowed to fade away very quickly. Where it concerns suicide victims particularly their body are not only detested but gets shabbily buried with no funeral rites. In their essay, "New Perspectives on "Natural" Death (Onwuchi) among Belgo-Igbo", Onah and Leman (2007) described how Igbo men, who committed suicide in faraway Belgium between 1996 -2006, were treated with ignominy by the Igbo in diaspora. Their bodies were neither flown home by the common effort of the Igbo community nor were they given any decent burial. It is a matter of a deep seated cultural and ideological force inspiring and commanding from within, irrespective of given spacio-temporal limitation (p.64). The Igbo are very keen to know what type of death a person suffered so as to determine on the possibility and nature of burials. Hence when a person dies, he is compulsorily laid in state for the people to inspect and conclude on the cause of death. In the words of Ubesie (1978) one custom common to the Igbos relating to death and burial is that at death, the corpse is washed, dressed and laid in state for people to behold. The reason for this practice is to enable the people testify that the deceased did not die of an invidious sickness (ajooya); And where the death is said to be natural that the people may further testify that there are no matchet cuts or bullet wounds suggesting that the deceased was shot or killed in a stealing or robbery attempt (p. 222).

Precisely, because ajoonwu(bad death) is a departure from the norm, it is rather within the descriptive boundaries of onwuchi(natural death), that the fertility of the Igbo burial ceremony is to be found. Hence this essay shall proceed to showcase on the death of an elderly woman on the one hand and that of a titled man (nze) on the other hand. 
Unlike the death of little children which is regarded as great calamity and so, does not merit elaborate religious and burial observances, the news of the death of an elderly woman entails elaborate, fecund, ceremonies with expensive and colourful rituals. For instance, at Ihiala in the central sub-cultural zone of Igbo land, when an elderly woman's death is announced to her relatives, it is immediately heralded by the sacrifice of a chicken by the family head before they mournfully proceed to behold her mortal body. There, they exhaust themselves in protracted dirge and dances at the end of which they will demand a number of articles with heavy ritual symbolisms. The prescribed articles are to be provided by the husband and children of the dead woman. These articles may include: goats, chicken, yards of cloth, some chalk and calm wood lotion are included. Again, according to Ilogu (1974), when the corpse is to be buried in the dead woman's family house, sacrifices are again offered (pp.47-48).

If on the other hand it is a titled man that had died, even richer burial symbolisms are observed especially as it appertains to religious rituals. Strange enough, the meanings of the symbolic elements required for burying the ozoman are not immediately obvious. Some are not even possible to come by, examples are the: mpinkita and aka agwo. In some places once a titled man is dead; the blood of a cock is collected and mixed with some special leaves and the resultant mixture used for a rite of absolution of the dead. This ritual is performed by a medicine man by administering a ritual hand washing of the dead with the concoction. In this way it is believed, all evils committed by the dead are caused to be absolved. What is more, all the shrines established by the dead man are decorated or rather encircled with palm tendrils (omunkwu). Then the corpse is washed, finger nails cut and the body laid in state amidst canon shots. As the dead lies in state, another white plumed cock is tied alive head downwards at the point where the dead man is "exposed". It is the firm belief of the people that by so doing, a peaceful passage of his soul to the ancestral land is guaranteed. Also, where the titled man is a priest of a particular deity, a medicine man is invited to detach him from the cult. Similarly, if he has involved himself in much sorcery, his cult items are all thrown away precisely as depotentiated. Ogbalu (1979) describing this observes as follows: 
If the dead man happens to be a chief priest of any deity, a medicine man is invited to ritually separate him from the deity. Where it happened that the dead involved himself in much sorcery and/or charms in his lifetime, his cult objects/charms are thrown away for the reason that the Igbo believes that a man's sorcery or charm dies with him (p.103).It is also customary before interment to make a divinatory inquiry (ijuase), as to whether the spirit of the dead man will trouble any person after burial. The reason for such inquiry is to scout for a remedy and/or forestall such possible infernal invasion.

Now, as the decisive moment of committal to the earth draws near, the all important ritual of Igwaozu aka or its hermeneutical alternative of iwankitaanya is performed. These rituals are done with the greatest solemnity in the places that observe them and they are accorded to only a very distinguished titled man (Dike). Iwankitaanya is performed to create a divide between the dead and the living. According to Ubesie (1978) the rite of iwankitaanyais done with a view to dissociating the dead from the world. It is the belief of the Igbo that if it is not done, the spirit of the dead will continue to roam the world causing afflictions and severe damages to the people (p. 223).

This ritual is satisfied by killing a dog and pouring its blood into the eye of the dead man. In those cultural areas that adopt the Igwa aka paradigm, a ram is killed and the blood sprinkled on the chest of the dead. After that, a cock is torn via its oral cavity into two parts and the blood dropped into the eye of the dead man. This having been done the dead titled man's head is decorated with abubaugo and is ready for interment. Ubesie (1978) reports that the moment annri man cuts off the "eririozo", committal is set (p. 226). Accordingly, before his corpse is buried, a goat and or a cow according to his children's or relations financial means, is slaughtered and the blood poured into the earth where he is to be buried. Soon after the burial the wives of the man wash their hands with shrubs known as akoro and ujiji for four times at the women's uke shrine so as to absolve themselves from their husband's death. None of his wives would eat until she had performed this ceremony. The white drum will then announce the putting down into the mother earth of the corpse and continue to be announced by being played for seven native weeks. According to Ilogu (1974), prayers and 
incantations are said to the spirit of the dead man's soul and for purposes of punishing any human being who in one form or the other might have caused the death of this titled man (p. 48). Normally, titled men and distinguished men of worth are usually buried by mid-afternoon, "mgbeanwukwurun'isi."

After laying down the remains, the women are invited to add the symbolic sand into their husband's grave. This is called "ikponyeajan'anya." Alternatively, a goat is killed and one of its limbs is put into the grave. There are varied (cultural) customs and practices adopted as the finalizing rites before the tomb is then covered. As the funeral goes on, according to Ogbalu (1979), it is the practice in some places that whatever is cooked in terms of food is put in a bowel and carefully placed on the way to the grave side (p. 108). When the burial ceremonies are over, the wives of the dead go into a sacred isolation called iban'nso. This lasts for two monthsa strenuous period of staying in one place without taking bath and without changing clothing. Neither the environment is swept nor the kitchen cleaned. The woman heralds each breaking day with cries. According to Ogbalu (1979), at the end of the isolation period, iputananso, an elderly nwaada cleanses the isolation, accompanies the woman to throw away all the debris, gives her a haircut, takes her to the stream to wash her body and helps her change her clothing (p.108). This culture as it where has persisted till the present times though with less intensity.

A significant aspect of the pristine Igbo burial ceremony is the whole issue of the second burial (ikwaozu). According to Мтио (1998), it is usually heavily festive and serves to ensure the home going of the spirit of the deceased (pp. 67-68). If the second burial was not performed, the proper inheritance of the late father's property could not be finally settled. What was worse, the extended family, according to Ilogu (1974), would be harassed by the hovering spirit of the dead person who had not properly settled down with the other ancestral spirits (p. 67). The second burial is usually a time of feasting rather than mourning. To the affected family, they feel happy that they have succeeded in making a great send off for their departed member to the spirits world. In-laws, friends and well wishers will make presentations one after another. 


\section{In Yoruba Culture}

As it is among the Igbo, age, circumstances of death and the social status of the dead determined the type of burial to be accorded. Generally, when an aged and respectable man dies a good death, the corpse is quickly covered in a mat while the relatives spread the messages concerning the death. In response, people troupe out to pay their last respect to the deceased. Simultaneously, the corpse is washed, and the hair plaited if a woman. In the case of a man, the hair is either shaved off or well combed. Customarily, the first born son of a man should first pour water on the father's corpse. Here, much importance is attached to the washing ritual as it is believed that one has to be clean in order to be admitted into the abode of the ancestors. Any corpse not so washed will become a wandering ghost- iwin or isekun. Awolawu (1979) noted that after the bath, the corpse is dressed in beautiful and dignifying clothing. It is brought into the sitting room and laid on a well decorated bed to lie in state. Music, dancing and feasting begin. There is also the firing of guns outside. The boom of a gun is a sign of respect for the deceased and a means of announcing to the general public that some great event has occurred. Lying in state lasts for two or three days under special treatment to prevent decay. Within those few days, the bedding and clothing worn by the deceased are regularly changed by children and relatives as a mark of honour. Enormous donations in cash and kind are made and those were to be taken by the dead to the great beyond (p.55).

The Yoruba aborigines do not bury people in the public cemeteries but in the family compound sometimes in the person's particular room. To bury outside the family compound appears like throwing away and loosing contact with the person totally. This is because regular ancestral veneration which involves pouring libation, breaking kola nuts and praying on the grave of the deceased will not be at the best of status in the next world and would be unable to bestow favour on the living descendants. Precisely, interment takes place in the evening but before then, the body is once more laid out in a couch amidst great dancing and performances. A little before sun set, the body is wrapped up in colourful clothes and taken to the grave in a long solemn procession. 
Izunwa: Customary right to befitting burial...

There, the corpse is carefully laid down in the grave. What is more, according to Awolawu (1979),

Beautiful clothing, pieces of silver, money and all that the departed is expected to require in the next world are provided... an animal is immolated and the blood is poured into the grave. It is believed that the sacrificial animal accompanies the deceased to the next world (p. 55).

The immolation of the sacrificial animal replaced the more ancient practice of burying kings with their slaves and wives. What is more, it is inferred from this practice of accompanying the dead with materials and articles used on earth that the dead were expected to enjoy in the afterlife the same socio - economic advantages which they had possessed in this world. As the grave is ready to be covered, there is much wailing by relatives even as they throw mud on the corpse asking him to do one thing or another for them and sending messages to their other ancestors.

\section{Among Tiv People and Culture}

As in many other cultural orientations, death among the Tiv people is categorized into the good and bad death. Notice, as Gbenda (2005) highlights that the distinction between these two categories is the same as in Igbo culture (p. 125). This typology as usual is fundamental to the nature of the burial to be accorded. Death of any person in this culture is usually announced with loud cries, canon shots, and perhaps if a wealthy man, the illu or indyer. Essentially, the indyer is used to inform the ancestors of the coming of a relative so that they get ready to receive him or her. After the sending of the advance information to the ancestors, then comes the great death inquisition (kuorun). According to Moti and Wegh (2001) kuorun is a process by which the Tiv investigate into the cause of the death of their family members (p. 64). These customs flow from their belief that death does not just occur, it is always caused by some diabolism. Processes, leading to the identification of the person or group responsible for the death starts with accusations and counter accusations among the dead person's patrilineal and matrilineal 
lineage which often leads to customary post-mortem surgery. Where no cause is found out, the person is accused of causing his own death via bad life style. Where the deceased is found to have lived a bad life, according to Gbenda (2005), the witches could remove him from the grave at night and give such a person great torture for the atrocities he/she committed (p. 128). If the dead person during his life time offended any deity (Akombo), a particular ritual is performed over his body with a foul or goat. This is done, according to Torkula (2001), to appease the particular Akombo and to prevent its harmful visitation on the society or relatives (p. 52). To get the corpse ready for committal to the earth, an elderly woman has to wash it. This is meant to enable the person to get into the ancestral world very neat and well dressed as to be received by the spirit world. Normally, the body will then be covered with any traditional attire such as anger, gbagire or tugudu.

For the Tiv, committal to the earth under normal circumstances must not exceed one day because it is an occasion for mourning and not of social celebration. Burial is usually done in a strategic place in the family compound or in the sitting room (ate) or perhaps near the compound. However, those who died bad deaths, like those who died of dreaded diseases, are buried in the outskirts of the compound or village. Indeed, there are many factors affecting where a person is buried. Married women are usually buried along the road leading to their maternal home, so that when her people will come for the customary exhumation, they will find it easy. Graves are also cited in such a way that guards sitting at the gate will be able to see and apprehend those who caused his death, in the event that they come to exhume the corpse for ritual purposes as usual. What actually determines the nature and size of the grave is the status of the person that died. According to Oso (1978), provisions are also made for recess graves (p.78).

Lying in state among the Tiv is done by getting the dead seated in his ate for final homage. In the grave, the dead is placed with face toward the east or of the direction of the rising sun- the source of all energy. This symbolizes the direction of the Tiv entry into the Benue valley and facilitates easy exhumation when necessary.Very importantly, the Tiv do not bury people with articles packed into the grave. They believe that this will obstruct 
exhumation, and may even cause another death. What they do is to create a shade over the grave where such things are kept for after-life use. Next, the Tiv bury their dead once and for all time. The whole issue of second burial is non-existent. Another aspect of Tiv burial ceremony that calls for attention is the customary exhumation: just on the first night after the burial, there comes an exhumation of the dead. This is an act of supernatural revival mediated by experts and witches. Details of what happens upon exhumation, is beyond the limits of the present essay. But suffice it to know that it is the belief of the people that upon exhumation, the dead is brought back to life whence the witches query him or her amidst playing and dancing, and where perchance the victim was wicked while alive, he or she is killed a second time being cut into pieces, to be consumed by the one who may have killed the deceased previously. The witches take home specific parts of the person's body for meat. Those who died of contagious diseases are never exhumed.

\section{In the Esan Culture}

It is indeed interesting to discover once more, that the Ishans of Edo state in Nigeria, also distinguish between good and bad death. In their belief, those who conducted their affairs with honour while they were alive are thought to continue their life elsewhere. From there, they commune with the living as often as is necessary. Hence, according to Edogiawerie (2007), "burial rites for those who lived good and commendable lives are more or less a send forth to the world beyond" (p. 132). In line with the foregoing, upon the death of any person, relatives and friends are quickly informed while preparations for the final burial are put in the pipeline.

Among the many rites that accompany the burial are:

1. Washing of the corpse- it is the onus of the peers and family members to wash the corpse in the presence of the eldest son.

2. Post-Mortem Examination- A compulsory post-mortem examination usually carried out by the family of the deceased is done to determine the moral quality of the person's life, especially as to whether or not he is a witch or wizard. Actual technicalities involved in the post-mortem are known and carried out by the elders in the presence of 
the children or siblings of the departed member. According to Edogiawerie (2007), there are inherent signs in the heart $(u d u)$ of the departed relative which goes to prove the moral status of the dead (p. 132). Where it is found out that the dead man is vicious, the Azien bi os-o, which is the pot of evil, is ritually removed and the dead absolved upon the request of the relatives. This is necessary for their hope in reincarnation. This is however kept tight secret among those present at the conduct of the post-mortem. If on the other hand, the person is discovered to be pure in heart, he or she receives praises by marks with the orhue that is the traditional white chalk. Added to this, prayers are offered to God through the ancestors on his or her behalf. If the postmortem reveals that the dead man is of good trado-moral integrity, the mourning is done in white or other light coloured clothes than in black. It is the case that befitting burials when accorded to any person causes such a person to gain admittance into the land of the ancestors.

In all, burial ceremony in Esan culture lasts for the maximum time of twenty-one days and the minimum of three. Suffice it to record that Esan burial culture is one of the most elaborate and complex among the parallel cultural patterns in Nigeria.

\section{Burial Ceremonies as Demonstrative Matrix for Afterlife Beliefs}

We notice that of all the creatures on earth, only man precisely as self conscious, sustains the sense and the fear of death. Animals may struggle to live, trees may present some kind of inertia against fall but there is no indication that they fear death. This has been allegorically demonstrated through the aid of pictures showing lions hunting their preys. Here, the apparent fright of a herd is much more probably a kind of expression of animal energy, the sheer delight of violent muscular activity, the absence of real fear being evident, according to Custance (1975), from two facts:

...the first being that the herd stop its flight instantly and resumes non-challant feeding the moment flight is no longer necessary and the second being that the animals nearest to the creature captured by the 
predator show no concern whatever in its fate. It is generally agreed that loss of appetite is a genuine evidence of fear. That such animal should halt their flight and return at once to grazing suggests the total absence of fear in the ordinary sense. And that those who escaped should show no interest in the fate of the one which did not, even though the lion may be eating it in their presence, seems to demonstrate the complete absence of anticipation of death (pp.64$65)$.

Since only man of all the members of the animal kingdom, has sense and fear of death, Modin's position that the death of man is different from the death of other beings inferior to him is somewhat sustainable. This is because the differentials in fear and sensitivity to death can only arise out of a peculiar difference in the nature of man or better put, out of a particular relation to life, death and afterlife. Hence the death of other animals is simply an automatic, mechanical event. Indeed, animals die; they do not predict it, study it, prepare for it or look beyond it. Man instead has consciousness of death; he can make it a subject of meditation during his whole life, and can pledge his life for death. He can, according to Mondin (1985), make death the most important act of his existence, as martyrs do (p. 268). In fact, the rich beliefs, many values and fertile ideas which emerge from man's sense of and relation to death, is further shown in this, that "it is only man who thinks of burying his dead." This is true even from the dawn of history. Science News (1975) reveals that in the Shanidar cave in Iraq were found several Neanderthal bodies buried on beds of eight different flowers and soft branches (p.108). Other Neanderthal bodies in France are painted with ocher and adorned with collars and arm rings. The Neanderthal people, according to Cosgrove (1977), therefore confronted death ritualistically and with concern (p. 61). As it were, the phenomenon of burying the dead which is an exclusive preserve of men, goes to show the very fact that they possess the distinct sign that death is something for them at a highly symbolic milieu, a meaning- field inaccessible by the merely connative- animal nature. 
The point of this essay is that according to Ebeh (2007), "even though death is so close and so common to human life and experiences, it is being viewed differently by different peoples and a people's view is so culturally conditioned that a good deal of the time, the people present different stories about the next world. The people's view about the next world determines how they buried their deceased members" (p.91).

\section{Evaluation}

These burial customs discussed above can, in accordance with the Evidence Act (2011), be proved by oral evidence; a good number of them have already been judicially noticed (sec 16). But section 18(3) of the Act provides that in any judicial proceedings where any custom is relied upon, it shall not be enforced as law if it is contrary to public policy or is not in accordance with natural justice equity and good conscience. Thus, in the preferred rendition of Asien (2005), to be applicable, a rule of custom must satisfy the following criteria namely;

a) The rule must not be repugnant to natural justice, equity and good conscience.

b) The rule must not be incompatible either directly or by implication with any law for the time being in force.

c) The rule must not be contrary to public policy.

Without doubt, from the studies carried out in this paper, some aspects of the burial customs and observances are on the face of it retrograde and barbarous. They fly in the face of the law, public policy, equity and good conscience and should be struck down. This is without prejudice to the need to promote the customs for what they stand for and/or symbolize.

Note too that a community construction and/or reading of all the Nigerian cultures understudied in this paperdiscloses that each culture sustains some idea of afterlife. This afterlife idea and its implications are discernible from the various burial/funeral ceremony symbolisms. As it were, the ceremonies standout as the statute book for predicting and disclosing the eschatological dimension of a culture. Hence, from the ceremonies, the content of the afterlife beliefs of a people can be predicted reasonably. This 
same afterlife belief in turn influences the way of life of a people in so far as humans live religiously with a view to achieving existential perfection of their being and destiny. Indeed, when people believe a thing to be true, it becomes true to their circumstances and regulates the conduct of their life. Beliefs are thus tutelary. They enjoy temporal and existential priority to action. To this extent it can be said that action follows LexcredendiLex Vivendi. This maxim too is continuous with the metaphysical axiom which holds that action follows being - agree sequitoresse.

Suffice it to say therefore that the manifold rules of afterlife beliefs sustained in a society directly influence the quality of popular behavior and invariably the temper of the social order.

Now, an evaluation of the burial/funeral ceremonies in most Nigerian cultures disclose motifs of, remedy retribution, separation, detachment, absolution, forgiveness, depotentiation/potentiation and finally reincarnation (return). All these and many more are intuitions of afterlife from differential considerations and they operate to mould/remould peoples conduct in society albeit imperceptibly.

Throughout Africa, peaceful transition to the ancestors has always been shown to be a function of a befitting burial ceremony. Hence various rich rituals are carried out to cause the deceased to receive their eschatological accomplishment. Thus among other religion, the quality of burial does not go to determine final destiny as such but in Africa it does. Integrally, the burial, its symbolisms, procedures and all are culturally bound, even as we find close similarities in the many Nigerian cultures.

It is not possible to exhaust all the aspects of burial ceremony in a culture, not to talk of "Nigerian cultures" hence, elements considered to be largely representative in a few cultures are in this paper extemporized for comparative considerations and general appreciation. Notice also that today most of the symbolisms and rituals have gone into abeyance as Christianity and Islam forcefully corrode the strongholds of our cultural bearing while generating monolithic cultures albeit alien. There is therefore the need to re-connect with the traditional and ritual symbolisms replete in our burial ceremonies if we are to appreciate well enough the deeper meanings of life and death. 
Burial ceremonies provide the single richest matrix of cultural symbolism because many things are celebrated, life, death and afterlife. At such ritual times, a people's shared perception about the three realities receives fertile imaginative and emotive responses. It is all the more true because, in trying to symbolize intuitions of what is rather not given with exactitude, much expansion of the apparatus of feeling, introspection and synthetic capacities are applied. The result will be and is usually an outburst of a plethora of cultural and ritual symbolism. At burial, life and death are being reconciled with highly potent connective symbolisms, because in Africa, when one person dies, the community dies in him but because the community continues to live, the person lives again in the community. Perhaps this explains not only the concentration of similar but parallel rites of burial but also why burials constitute the most effective event of re-union for the African peoples. Everybody goes home for burials because life, death and afterlife are being celebrated. Added to it, individuality and communality are being reconciled in the fact of communal experience of individual death.

\section{Conclusion}

Note that the right to a befitting burial is next to right to life in the hierarchy of longings of the African spirit. It is the conditioning condition for afterlife destiny and social harmony here on earth. It has implications transcending mere rites of passage. Like church sacraments they are epiphanies of inward meanings and are capable of effecting what they symbolize. Without doubt, the fate of a man's afterlife destiny is substantially determined in proportion to how this right is accorded to the dead. This right too is enforceable on behalf of the dead in unique customary ways. For instance, where a man dies and the children have not performed for him the requisite burial/funeral rites precisely as a right due to him, no other member(s) of that family will be accorded such right upon death until such a time, the man who died first is given a befitting burial/funeral. What more; this right is further enforceable in the sense that the one who ought to but negligently fails to accord his parents such right to befitting burial, shall not inherit as heir. He automatically loses his right of inheritance (Nwafuruibe, 2016). 
Befitting burial right also has a way of giving back to the society (community). While striving to secure and/or merit the right, men conduct their affairs with honour and nobility, and in that way build the moral fabrics of the community.

Suffice it to conclude that the various burial customs forming the manifold right of befitting burial possess the qualities of; antiquity vested rights, certainty, precision reasonableness, notoriety and are consistent with other customs and/or rights (Iheme,1994).

\section{Recommendations}

1. It is hereby recommended that by the operation of the law relating to applicability of customs, all aspects of burial customs which are barbarous and retrograde should be struck down.

2. It is further recommended that the eschatological dimension of Nigerian cultures be emphasized in undergraduate general studies (GS) particularly under Nigerian Peoples and Culture. The united evidence of afterlife, being borne by the cultures, will no doubt provide an incentive for students' positive ethical life in campus and society.

3. The leadership of mainline churches especially Christian denominations should understudy the significance of burial ceremonies in the Nigerian cultures so as to isolate neutral and positive elements for inculturation. This too will end some of the prevailing religious violence and/or intolerance in our polity by promoting inter-religious dialogue.

4. It is further recommended that the different cultural traditional religious centres in Nigeria should embark on popular cultural and religious awareness in which the people should be made to appreciate the commonalities in the destiny and end of man as evidenced in the symbols of their various cultures. This can enhance/promote unity in a pluralistic society like Nigeria.

*Maurice Okechukwu Izunwa is a Lecturer in the Department of International Law and Jurisprudence, Faculty of Law, Nnamdi Azikiwe University, Awka 


\section{References}

Agbasiere, J.T. (2000). Women in Igbo life and thought. London: Routeledge.

Alaezi, O. (1990). "Nigerian Cultures: Need for Adaptation, Intercultural Education and Communication", in Ikenga

Metuh E. and Ojoade O., Nigerian cultural heritage. Onitsha: IMICO.

Asein, J.O. (2005), $2^{\text {nd }}$ Edition. Introduction to Nigerian Legal System. Lagos: Ababa.

Awolawu, J.O. (1979). Yoruba beliefs and sacrificial rites. Essex: Longman 1979.

Azikiwe, N. (1964) Tribalism: A pragmatic instrument for national unity. Enugu: Eastern Nigeria.

Boston, J.S. (1968). Igala kingdom. Ibadan: Oxford University.

Brownoski, J. (1973). The ascent of man. Boston: Brown and

Company, 1973.

Cosgrove, M. (1977).Essence of human nature. Michigan:

Zondervan.

Custance, A.C. (1975). Man in Adam in Christ. Grand Rapids:

Zondervan.

Dewey, J. (1929). Individualism old and new, New York: Capricon Books, 1929.

Ebeh, J.I. (2007). "Death Grave and Burial Ceremonies Among the Igala people of Kogi State", in Ukagba G. The kpim of death. Canada: Trafford.

Edogiawerie, M.K. (2007). "A Critical Examination of the Esan Concept of Death”.inUkagba G. (ed.) The kpim of death. Canada: Trafford.

Falola T. (2001), Culture and customs of Nigeria. Connecticut: Greenwood.

Gbenda, J.S. (2005). Eschatology in Tiv traditional religious culture an interpretative enquiry. Enugu: Chuka Educational.

Hinnels, J.R. (1995). The penguin dictionary of religions. $2^{\text {nd }} \mathrm{ed}$.

London: Penguin Book.

Homans, G. (1974). Social structure in its elementary forms. New York: Harcourt Brace Jovanovich, 1974.

Iheme, B.A (1995), A handbook on jurisprudence and legal theories. Owerri. 
Izunwa: Customary right to befitting burial...

Ikenga-Metuh, E. (1987). Comparative studies of African traditional religion. Onitsha: IMICO publications.

Ilogu, E. (1974). Christianity and Igbo culture. Onitsha: University. Kalu O. (1979). 'Church Presence in Africa. A Historical Analysis of the Evangelization Process in Appiah, K. and Tores, S. (ed.) African theology en route: papers from the PanAfrican conference of third world theologians December 1723, 1977, Accra-Ghana. New York: Orbis books.

Mithnow, R. (1987). Meaning and moral order: explorations of cultural analysis. Berkeley: University of California, 1987.

Mondin, B. (1985). Philosophical anthropology. Bangalore:

Theological Publications in India.

Mooney, Knox \& Schacht (1997). Understanding social problems. Minneapolis, West.

Moti, J. S. \& Wegh, S. F. (2001).An encounter between Tiv religion and christianity. Enugu: Snaap.

Nwala, T.U. (1985) Igbo philosophy. Lagos: Literamed.

Ogbalu, F.C. (1979). Omenaala Igbo, Onitsha:

University.

Onah S.O. \& Leman J. (2007). "New Perspective on 'Natural Death' (onwuchi) among Belgo-Igbo Migrants" in Ukagba G., The kpim of death. Canada: Trafford.

Opata D.U. (1998). Essays on Igbo world view. Nsukka: A.P. Express.

Oso, S.O. (1978). An introduction to West African traditional religion. Ado Ekiti: Omolayo Standard.

Torkula, A.A. (2001). "Tiv Cultural Grave".First national workshop on marriage and burial customs. Kaduna: Institute of Management Consultants.

Ubesie, T. (1978).Odinalandi Igbo. Ibadan: Oxford University. Ukagba, G. (2007). The kpim of death: essays in memory of Rev. Fr. Prof. Panteleon Osondu Iroegbu. Canada: Trafford. 